gender-matched patients with RA. The results were analysed with respect to clinical and laboratory parameters such as data on GC treatment (frequency, duration defined as start of treatment until timepoint of measurement, actual and cumulative dose), csDMARD and bDMARD (including as well tsDMARDs) therapy, serological parameters (Vitamin D, alkaline phosphatase, calcium, inflammatory markers and rheumatoid factor) and functional status (e.g. Health Assessment Questionnaire (HAQ), sporting activities). Statistical analyses were performed descriptively using mean and standard deviation, t-tests for metric variables, and chi-square tests for nominal variables. For subgroup analyses with less than 30 patients per group, tests for non-normally distributed data were used due to the lower test power.

Results: RA patients showed significantly lower means of bone density values (minimal T-score, $p=0.03$ ) than PsA patients leading to a higher frequency of osteopenic bone densities $(p<0.005)$. However, no differences in the frequency of osteoporotic bone densities could be detected. PsA patients reported a significantly longer disease duration and a higher current GC dosage. In contrast, the frequency of current GC intake was higher in RA patients. Although the calcium intake was higher in the RA group, neither blood levels of calcium and vitamin D, nor the cumulative GC dose (GCCD) or duration of GC therapy could indicate a causal relationship for the differences observed in bone density values between the two groups. The frequency of csDMARD therapy did not differ significantly between PsA and RA patients while the frequency of bDMARD therapy was higher in the PsA group $(p=0.04)$.

Conclusion: The lower bone density in RA patients seems not to be fully explained by higher GCCD, disease duration or higher levels of inflammation. However, RA patients had a higher frequency of current GC intake. Additionally, differences in bone density between the two groups could be related to the higher number of bDMARD therapies in PsA patients, but further investigations like multivariate analyses with higher numbers of patients are necessary. Furthermore there is more need for research on possible molecular and genetic factors in PsA, which are protecting from low bone density.

Disclosure of Interests: Desiree Freier: None declared, Edgar Wiebe: None declared, Robert Biesen: None declared, Thomas Buttgereit: None declared, Sandra Hermann: None declared, Timo Gaber: None declared, Frank Buttgereit Grant/research support from: Amgen, BMS, Celgene, Generic Assays, GSK, Hexal, Horizon, Lilly, medac, Mundipharma, Novartis, Pfizer, Roche, and Sanofi. DOI: 10.1136/annrheumdis-2020-eular.3447

\section{AB0768 TREATMENT WITH TOFACITINIB IN REFRACTORY PSORIATIC ARTHRITIS. MULTICENTER STUDY OF 87 PATIENTS IN CLINICAL PRACTICE}

E. Galindez ${ }^{1}$, D. Prieto-Peña ${ }^{2}$, J. L. Martín-Varillas ${ }^{2}$, B. Joven-lbáñez ${ }^{2}$, O. Rusinovich' ${ }^{2}$, R. Almodovar' ${ }^{2}$, J. J. Alegre-Sancho' ${ }^{2}$ L. Mendez Diaz ${ }^{2}$, A. Sellas-Fernández ${ }^{2}$, À. Martínez-Ferrer², R. Garcia de Vicuna ${ }^{2}$, C. VentínRodríguez $z^{2}$, J. Ramirez ${ }^{2}, M_{\text {. Moreno }}^{2}$, M. J. Moreno², M. D. C. Castro Villegas ${ }^{2}$, A. Crespo Golmar ${ }^{2}$, N. Palmou-Fontana ${ }^{2}$, F. Ortiz Sanjuan ${ }^{2}$, X. E. Larco Rojas' ${ }^{2}$ A. J. Mas $^{2}$, C. Y. Soleto' ${ }^{2}$ I. Gorostiza' ${ }^{1}$, M. A. González-Gay², R. Blanco ${ }^{2} .{ }^{1} \mathrm{HU}$ Basurto, Bilbo, Spain; ${ }^{2} \mathrm{NHS}$, Madrid, Spain

Background: Tofacitinib (TOFA) is the first JAKi approved for psoriatic arthritis (PsA) in Europe (July 2018). TOFA has shown efficacy in refractory patients to antiTNF in Randomized Clinical Trials (RCT) (Gladman D. NEJM 2017; 377: 1525-36). Objectives: To assess efficacy and safety of TOFA in clinical practice (CP). To compare the profile of CP with RCT

Methods: Study of 87 patients of CP with PsA treated with TOFA; Results are expressed as percentage, mean $\pm \mathrm{SD}$ or median [IRQ].

Results: 87 patients $\left(28 \% / 590^{\star}\right)$, mean age of $52.8 \pm 11.4$ years (Table 1$)$. Pattern of joint involvement was: peripheral $(n=60)$, axial (1) and mixed (26). Presented also enthesitis (49.4\%), nail involvement $(30.2 \%)$ and dactylitis (31\%).

Prior TOFA, most patients $(80 \%)$ received oral prednisone, synthetic immunosuppressants (mean 2.3 \pm 0.9$)$ and biological therapy (BT) $(3.6 \pm 1.9)$ : etanercept $(n=58)$, adalimumab (54), infliximab (31), golimumab (37), certolizumab (30), secukinumab (54), ustekinumab (39) and ixekizumab (2). Apremilast was used in 17. After a mean follow-up of $12.3 \pm 9.3$ years from PsA diagnosis, TOFA was started $(5 \mathrm{mg} / 12 \mathrm{~h})$. In $48(55.2 \%)$ TOFA was used in combined therapy: methotrexate (30) and leflunomide (15). In the remaining 39, monotherapy was prescribed.

Patients of CP compared with RCT have a longer duration of PsA, worst functional disability (HAQ) and received a higher proportion of corticosteroids and BT (anti-TNF and non-anti-TNF) (Table 1).

Patients improved in activity indexes (PASI, DAS28, DAPSA) and laboratory test (table 2). Minor side effects were reported in 21 patients (gastrointestinal symptoms), and TOFA was discontinued in 29 due to inefficiency mainly.

Conclusion: Patients of CP had a longer evolution and received a greater number of biologics than those of RCT. TOFA as in RCT seems effective, rapid and relatively safe for refractory PsA.
Table 1. Baseline features

\begin{tabular}{lcc}
\hline & $\begin{array}{c}\text { CLINICAL TRIAL } \\
\text { Gladman } \\
\mathrm{N}=131\end{array}$ & $\begin{array}{c}\text { CLINICAL PRACTICE } \\
\mathrm{N}=87\end{array}$ \\
\hline Age, years (mean $\pm \mathrm{SD})$ & $49.5 \pm 12.3$ & $52.8 \pm 11.4$ \\
Sex, $\mathrm{n}(\%)$ & $67 \mathrm{M} / 64 \mathrm{~F}(51 / 49)$ & $59 \mathrm{M} / 28 \mathrm{~F}(68 / 32.2)$ \\
Duration PsA, years (mean $\pm \mathrm{SD})$ & $9.6 \pm 7.6$ & $12,3 \pm 9.3$ \\
HAQ-DI & $1.3 \pm 0.7$ & $1.4 \pm 0.7(\mathrm{n}=26)$ \\
Swollen joint count, mean $\pm \mathrm{SD}$ & $12.1 \pm 10.6$ & $5.7 \pm 5.8$ \\
Painful joint count, mean $\pm \mathrm{SD}$ & $20.5 \pm 13.0$ & $8.0 \pm 6.6$ \\
Elevated CRP, $\mathrm{n}(\%)$ & $85(65)$ & $55(63.2)$ \\
PASI score, median $[\mathrm{IQR}]$ & $7.6[0.6-32.2]$ & $9.0[4.2-15]$ \\
Oral glucocorticoid, $\mathrm{n}(\%)$ & $37(28)$ & $44(50.5)$ \\
Concomitant synthetic DMARDs, $\mathrm{n}(\%)$ & & \\
- Methotrexate & $98(75)$ & $30(34.4)$ \\
- Leflunomide & $12(9)$ & $15(17.2)$ \\
- Sulfasalazine & $21(16)$ & $6(6.9)$ \\
- Others & $2(2)$ & \\
N. of previous TNF inhibitors, mean $\pm S D$ & $1.7 \pm 1.0$ & $2.4 \pm 1.4$ \\
Previous use of other biological no anti-TNF, $\mathrm{n}(\%)$ & $11(8)$ & $68(78.2)$ \\
\end{tabular}

Table 2. Improvement at $1^{\text {st }}, 6^{\text {th }}$ and $12^{\text {th }}$ month

\begin{tabular}{|c|c|c|c|c|}
\hline & $\begin{array}{c}\text { Baseline } \\
\mathrm{n}=87\end{array}$ & $\begin{array}{l}\text { 1st month } \\
\mathrm{n}=77\end{array}$ & $\begin{array}{l}\text { 6th month } \\
\qquad \mathrm{n}=52\end{array}$ & $\begin{array}{l}\text { 12th month } \\
n=20\end{array}$ \\
\hline Nail involvement, n (\%) & $17(19.5)$ & & & \\
\hline Improvement, $\mathrm{n}(\%)$ & & $5(35.7)$ & $6(60)$ & 5 (83.3) \\
\hline Enthesitis, n (\%) & $28(32.2)$ & & & \\
\hline Improvement, $\mathrm{n}(\%)$ & & $8(47.1)$ & $10(58.8)$ & $3(50)$ \\
\hline Dactylitis, n (\%) & $16(18.4)$ & & & \\
\hline Improvement, n (\%) & & 9 (69.2) & $6(85.7)$ & $0(0)$ \\
\hline CRP mg/dl, median [IQR] & $1.9[0.3-5]$ & $0.5[0.1-2.2]$ & $0.5[0.3-1.2]$ & $0.4[0.4-3.7]$ \\
\hline$p$ (vs baseline) & & 0.004 & 0.005 & 0.66 \\
\hline DAS28, median [IQR] & $4.8[4.1-5.40$ & $3.7[2.8-4.6]$ & $2.8[2.2-3.8]$ & $2.9[2.2-3.7]$ \\
\hline$p$ (vs baseline) & & $<0.001$ & $<0.001$ & $<0.001$ \\
\hline DAPSA, median [IQR] & 28 [18.41-34.05] & $15.5[10.1-25.7]$ & 9 [6.07-15] & $4.3[2.4-8]$ \\
\hline$p$ (vs baseline) & & $<0.001$ & $<0.001$ & $<0.001$ \\
\hline PASI, median [IQR] & $5[1-14]$ & $1.4[0-7]$ & $0[0-4]$ & $0.05[0-2.7]$ \\
\hline$p$ (vs baseline) & & 0.192 & 0.105 & 0.300 \\
\hline
\end{tabular}

Disclosure of Interests: E. Galindez: None declared, D. Prieto-Peña: None declared, José Luis Martín-Varillas Grant/research support from: AbbVie, Pfizer, Janssen and Celgene, Speakers bureau: Pfizer and Lilly, Beatriz Joven-Ibáñez Speakers bureau: Abbvie, Celgene, Janssen, Merck Sharp \& Dohme, Novartis, Pfizer, Olga Rusinovich: None declared, RAQUEL ALMODOVAR Speakers bureau: Abbvie, Celgene, Janssen, Lilly, Novartis, Pfizer.

, Juanjo J Alegre-Sancho Consultant of: UCB, Roche, Sanofi, Boehringer, Celltrion, Paid instructor for: GSK, Speakers bureau: MSD, GSK, Lilly, Sanofi, Roche, UCB, Actelion, Pfizer, Abbvie, Novartis, LARA MENDEZ DIAZ: None declared, Agusti Sellas-Fernández Speakers bureau: Abbott, Lilly, Celgene, Pfizer, Schering-Plough, Janssen, Novartis, and Nordic Pharma, À Martínez-Ferrer: None declared, Rosario Garcia de Vicuna Grant/research support from: BMS, Lilly, MSD, Novartis, Roche, Consultant of: Abbvie, Biogen, BMS, Celltrion, Gebro, Lilly, Mylan, Pfizer, Sandoz, Sanofi, Paid instructor for: Lilly, Speakers bureau: BMS, Lilly, Pfizer, Sandoz, Sanofi, Clara Ventín-Rodríguez: None declared, Julio Ramirez: None declared, Manuel Moreno: None declared, Maria jose Moreno: None declared, María del Carmen Castro Villegas: None declared, Antia Crespo Golmar: None declared, Natalia Palmou-Fontana: None declared, FRANCISCO ORTIZ SANJUAN: None declared, Ximena Elizabeth Larco Rojas: None declared, Antonio Juan Mas: None declared, Christian Y Soleto: None declared, Iñigo Gorostiza: None declared, Miguel A González-Gay Grant/research support from: Pfizer, Abbvie, MSD, Speakers bureau: Pfizer, Abbvie, MSD, Ricardo Blanco Grant/research support from: AbbVie, MSD, and Roche, Speakers bureau: AbbVie, Pfizer, Roche, Bristol-Myers, Janssen, and MSD DOI: 10.1136/annrheumdis-2020-eular.2903

\section{AB0769 THE IMPACT OF BODY MASS INDEX ON DISEASE ACTIVITY AND ENTHESITIS IN PSORIATIC ARTHRITIS}

S. Ganhão ${ }^{1}$, B. M. Fernandes ${ }^{1}$, S. Garcia ${ }^{1}$, F. Pinheiro ${ }^{1}$, M. Rato ${ }^{1}$, E. Mariz ${ }^{1}$, M. Bernardes ${ }^{1,2}$, L. Costa ${ }^{1}{ }^{1}$ Centro Hospitalar e Universitário de São João, Rheumatology, Oporto, Portugal; ' ${ }^{2}$ Faculty of Medicine of Oporto's University, Oporto, Portugal

Background: Overweight/obesity has increased exponentially in the last decades, becoming a huge Public Health problem. Moreover, an increase in adipose tissue is associated with an increased production of several proinflammatory cytokines and acute phase reactants. Higher BMI has been related with new bone formation including syndesmophytes and enthesophytes. In fact, besides 
rheumatologic conditions including Psoriatic Arthritis (PsA), enthesopathy can be a consequence of several clinical conditions including metabolic syndrome, mechanical injuries and degeneration.

Objectives: To evaluate the effect of body mass index (BMI) on disease activity scores and enthesitis scores in Psoriatic Arthritis.

Methods: Retrospective study including all the patients with PsA meeting the CASPAR criteria, beginning first-line biologic therapy at our centre. Demographic and clinical data were collected from the Portuguese database Reumapt. Statistical analysis was performed with SPSS. Continuous variables were compared through Spearman/Pearson correlations.

Results: The mean BMI was 26.8 (SD 0.5). In our sample of 119 PsA patients, $21.5 \%$ were overweight and $8.3 \%$ were obese. The mean age of patients was $46.3 \pm 1.03$ years; 60 female and 59 male. The median disease duration was 6.8 (0.3-33.8) years. At baseline mean (SD) disease activity variables were: DAS 28 4vESR 4.9 (0.2), ESR 33.2 (2.3) mm/h; CRP 2.35 (0.3) mg/dL, BASDAI 6.6 (0.2), ASDAS 3.9 (0.1), BASMI 3.7 (0.2), BASFI 5.8 (0.3), MASES 1.9 (0.3), SPARCC 2.3 (0.3). There were statistically significant positive correlations between BMI and MASES at baseline $(p=0.024, r=0.411)$ but there weren't with SPARCC, DAS 28 4vESR, ESR, CRP, BASDAI, ASDAS, BASMI and BASFI.

Conclusion: The data showed that patients with higher BMI values had higher enthesitis scores suggesting that overweight/obesity may have a negative impact on enthesopathy. Further studies are still needed to further understand that possible relationship.

References:

[1] Bakirci S, Dabague J, Eder L, McGonagle D, Aydin SZ. The role of obesity on inflammation and damage in spondyloarthritis: a systematic literature review on body mass index and imaging. Clin Exp Rheumatol. 2019 Apr 29.

Disclosure of Interests: Sara Ganhão: None declared, Bruno Miguel Fernandes: None declared, Salomé Garcia: None declared, Filipe Pinheiro: None declared, Maria Rato: None declared, Eva Mariz: None declared, Miguel Bernardes Speakers bureau: Abbvie, Amgen, Biogen, Eli-Lilly, Glaxo-Smith-Kline, Pfizer, Janssen, Novartis, Lúcia Costa: None declared

DOI: 10.1136/annrheumdis-2020-eular.4567

\begin{tabular}{|l|l}
\hline AB0770 & DESCRIBING A COHORT OF PATIENTS WITH \\
PSORIATIC ARTHRITIS ACCORDING TO THE \\
BODY MASS INDEX: EXPERIENCE IN A JOINT \\
RHEUMATOLOGY-DERMATOLOGY CLINIC
\end{tabular}

A. García-Guillén ${ }^{1}$, A. Laiz ${ }^{1}$, A. Lopez-Ferrer ${ }^{1}$, H. Park ${ }^{1}$, P. Moya ${ }^{1}$,

B. Magallares ${ }^{1}$, I. Castellví ${ }^{1}$, A. M. Millán Arciniegas ${ }^{1}$, C. Díaz-Torné ${ }^{1}$, S. Jeria ${ }^{1}$,

H. Corominas ${ }^{1} .{ }^{1}$ Hospital de la Santa Creu i Sant Pau, Barcelona, Spain

Background: Obesity is a predictor for the development of psoriatic arthritis (PsA) with a negative prognostic impact.

Objectives: We aimed to describe and characterize patients with PsA according to the Body Mass Index (BMI) in a joint Rheumatology-Dermatology unit (PAIDER).

Methods: We retrospectively reviewed patients diagnosed with PsA according to CASPAR criteria visited between May 2012 and May 2019 at the PAIDER clinic of our center. Data on demographic and anthropometric features, serologic findings, source of referral, cardiovascular risk factors and biological treatment were collected from clinical records. Patients were classified according to the $\mathrm{WHO}$ International Classification of nutritional status in normal weight (BMI $18.5-24.9 \mathrm{Kg} / \mathrm{m} 2$ ), overweight (BMI $25-29.9 \mathrm{Kg} / \mathrm{m} 2)$ and obesity (BMl $\geq 30 \mathrm{Kg} /$ $\mathrm{m} 2)$. A descriptive analysis was performed, and the differences between groups were evaluated using Chi2, T-Student and ANOVA tests. P-values $<0.05$ were accepted as significant.

Table 1.

\begin{tabular}{|c|c|}
\hline Baseline characteristics & $\begin{array}{c}\text { Total } \\
\mathrm{n}=393\end{array}$ \\
\hline Female, n (\%) & $199(50,6)$ \\
\hline Age, yrs, mean $\pm S D$ & $52,47(13,21)$ \\
\hline \multicolumn{2}{|l|}{ Source of referral, $n(\%)$} \\
\hline Dermatology & $117(29,8)$ \\
\hline Rheumatology & $219(55,7)$ \\
\hline Primary Care and Others & $22(5,6)$ \\
\hline Smoker, n (\%) & $97(25,8)$ \\
\hline High Blood Pressure (HBP), n (\%) & $106(27,7)$ \\
\hline Diabetes, n (\%) & $48(12,5)$ \\
\hline Hypercholesterolemia, n (\%) & $98(25,8)$ \\
\hline Hyperuricemia, $n(\%)$ & $32(8,6)$ \\
\hline HLA-B27 positive, $n$ (\%) & $68(21,6)$ \\
\hline $\mathrm{BMI}, \mathrm{Kg} / \mathrm{m}^{2}$, mean $\pm \mathrm{SD}$ & $28,15(5,87)$ \\
\hline Biological treatment, $\mathrm{n}(\%)$ & $166(43,2)$ \\
\hline
\end{tabular}

Table 2.

\begin{tabular}{|c|c|c|c|c|}
\hline $\begin{array}{l}\text { Characteristics according to } \\
\text { BMI }\end{array}$ & $\begin{array}{l}\text { Normal weight } \\
\quad n=118\end{array}$ & $\begin{array}{c}\text { Overweight } \\
n=112\end{array}$ & $\begin{array}{c}\text { Obesity } \\
n=118\end{array}$ & $P$ value \\
\hline Female, n (\%) & $66(55,9)$ & $52(46,4)$ & $62(52,5)$ & ns \\
\hline Age, yrs, mean $\pm S D$ & $47,92(14,08)$ & $54,71(11,75)$ & $54,48(11,54)$ & $<0,001$ \\
\hline Source of referral, $\mathrm{n}(\%)$ & & & & Ns \\
\hline Dermatology & $35(33,7)$ & $37(35,2)$ & $34(30,9)$ & \\
\hline Rheumatology & $63(60,6)$ & $61(58,1)$ & $70(63,6)$ & \\
\hline Primary Care and Others & $6(5,8)$ & $7(6,7)$ & $6(5,5)$ & \\
\hline Smoker, n (\%) & $37(33)$ & $23(21,1)$ & $31(26,7)$ & ns \\
\hline High Blood Pressure (HBP), n (\%) & $12(10,5)$ & $37(34,3)$ & $41(35)$ & $<0,001$ \\
\hline Diabetes, n (\%) & $7(6)$ & $9(8,3)$ & $30(25,6)$ & $<0,001$ \\
\hline Hypercholesterolemia, n (\%) & $19(17)$ & $24(22,2)$ & $45(38,5)$ & 0,001 \\
\hline Hyperuricemia, $n(\%)$ & $5(4,4)$ & $7(6,8)$ & $19(16,7)$ & 0,004 \\
\hline HLA-B27, n (\%) & $27(28,7)$ & $17(17,9)$ & $13(12,6)$ & 0,016 \\
\hline $\mathrm{BMI}, \mathrm{Kg} / \mathrm{m}^{2}$, media $\pm \mathrm{DE}$ & $22,58(1,78)$ & $27,46(1,55)$ & $34,42(5,08)$ & - \\
\hline Biological treatment, n (\%) & $47(41,2)$ & $45(40,9)$ & $66(55,9)$ & 0,032 \\
\hline
\end{tabular}

Results: During the study period 393 patients (50.6\% women) with a mean age of $52.47 \pm 13.21$ years were evaluated. Baseline characteristics are shown in table 1.

The mean BMI was $28.15 \pm 5.87 \mathrm{~kg} / \mathrm{m}^{2} .112$ patients $(32 \%)$ were overweight with a mean BMI of $27.46 \pm 1.55 \mathrm{~kg} / \mathrm{m}^{2}$ and 118 patients $(34 \%)$ were obese with a mean BMI of $34.42 \pm 5.08 \mathrm{~kg} / \mathrm{m}^{2}$. Of the obese patients, $80(67.8 \%)$ had obesity grade $1,28(23.7 \%)$ grade 2 and $10(8.5 \%)$ grade 3

Characteristics of the patients according to BMI categories are shown in Table 2 We observed that mean age was significantly higher in obese patients $(p<0.001)$, as well as the prevalence of cardiovascular risk factors such as HBP $(p<0.001)$ Diabetes $(p<0.001)$, dyslipidemia $(p=0.001)$ and hyperuricemia $(p=0.004)$ Obese patients also received more biological therapy $(p=0.032)$. A higher prevalence of HLA-B27 was observed in patients with normal weight $(p=0.016)$. No differences were found according to BMI regarding gender and source of referral. Conclusion:

- Almost $70 \%$ of patients with PsA visited in the PAIDER clinic of our center have a BMI above normal and more than a third of them are obese, mostly grade 1.

- In our joint clinic there are no differences in BMI regarding the source of referral of the patients.

Patients with obesity are older, have more cardiovascular comorbidities and receive more biological treatment significantly, which increases the complexity of their management and worsens the prognosis.

Disclosure of Interests: Andrea García-Guillén: None declared, Ana Laiz: None declared, Anna Lopez-Ferrer: None declared, HyeSang Park: None declared, Patricia Moya: None declared, Berta Magallares: None declared, Ivan Castellví Consultant of: Boehringer Ingelheim, Actelion, Kern Pharma, Speakers bureau: Boehringer Ingelheim, Actelion, Bristol-Myers Squibb, Roche, Ana Milena Millán Arciniegas: None declared, Cesar Díaz-Torné: None declared, Sicylle Jeria: None declared, Hector Corominas: None declared DOI: 10.1136/annrheumdis-2020-eular.1271

\section{$\mathrm{AB} 0771$ \\ DAPSA REMISSION/LOW DISEASE ACTIVITY IS ASSOCIATED WITH LOW PSAID12 IN PSORIATIC ARTHRITIS}

C. García-Porrúa $^{1}$, L. Fernández-Dominguez ${ }^{2}$, J. L. Guerra-Vazquez ${ }^{3}$, J. A. Mosquera Martínez ${ }^{4}$, J. Pinto-Tasende ${ }^{5}$ on behalf of GIGAPS. ${ }^{1} H U L A$, LUGO, Spain; ${ }^{2} \mathrm{CHU}$ Ourense, Ourense, Spain; ${ }^{3} \mathrm{CHU}$ Arquitecto-Marcide, Rheumatology, Ferrol, Spain; ${ }^{4} \mathrm{CHU}$ Pontevedra, Pontevedra, Spain; ${ }^{5}$ InibicCHU A Coruña, Rheumatology, A Coruña, Spain

Background: Psoriatic arthritis (PsA) has a prevalence of $0.17 \%$ in North-Western of Spain and patients suffer this disease have significant impact on daily life due to articular, dermatological and psychological symptoms. DAPSA VLDA/LDA $(\leq 14)$ is a therapeutic goal recommended by EULAR for clinical practice.

Objectives: Our aim was to assess the relationship between DAPSA index and PSAID questionnaire in routine clinical practice.

Methods: We performed a cross-sectional study of patient and physician reported outcomes. We obtained clinical information of patients with PsA attending clinic from October 2018 to October 2019. Data were collected from clinical records concerning age, gender, disease duration, joint counts, dactylitis, enthesitis, body surface area (BSA) of psoriasis, laboratory results (ESR and $\mathrm{CRP}$ ), HAQ, PsAID12, pain and global assessment from patient with numerical rating scale (NRS) and DAPSA index. Data were analysed using SPSS21. Logistic regression was used to assess patient reported outcomes which were associated with DAPSA VLDA/LDA.

Results: Data were available for 210 patient visits, $43 \%$ females. DAPSA $\leq 14$ was in 143 patients $(68.1 \%)$ and was associated with higher disease duration, OR $1.079(1.020-1.142,95 \% \mathrm{Cl}), \mathrm{p} 0.008$. DAPSA index was not associated with BSA ( $r$ 0.126, p 0.176). 